\title{
Integration of collagen matrices into the urethra when implanted as onlay graft
}

\author{
Kleber Sayeg, Luiz G. Freitas-Filho, Ângela Flávia Logullo Waitzberg, Victor Eduardo Arrua Arias, \\ Marcus Laks, Fernanda Mattos Egydio, Andréia Silva Oliveira \\ Department of Surgery (KS, LGFFilho, ML, FME), Department of Nephrology (ASO) and Department of \\ Pathology (AFLW, VEAA) - Federal University of São Paulo, Brazil
}

\section{ABSTRACT}

Objective: To assess the integration of decellularized heterologous collagen matrices into the urethra, when implanted with no cells or when seeded with autologous smooth muscle cells.

Materials and Methods: Eighteen New Zealand rabbits were randomly assigned to two groups: Group I ( $\mathrm{n}=9$ ) - animals undergoing urethral segment resection with interposition of a patch of heterologous collagen matrix seeded with autologous smooth muscle cells; Group II ( $\mathrm{n}=9$ ) - animals undergoing resection of a urethral segment with interposition of a decellularized heterologous collagen matrix patch. Two animals from each group were sacrificed on postoperative days seven, fourteen and twenty-eight; three animals from each group were sacrificed at the end of three postoperative months. At the end of the third month one animal from each group underwent urethroscopy for urethral integrity assessment and one animal from each group had its microcirculation image captured by a SDF device (Side-stream Dark Field - Microscan Analysis Software). One animal from each group in each euthanasia period underwent cystourethrography so as the urethra could be viewed at flow time. The matrices integration was assessed through histological examination using hematoxylin and eosin (HEtE), Masson trichrome (MT), Picrosirius red and Von Willebrand staining. In a blind study with two pathologists all the slides were studied.

Results: The matrices whether seeded or not with autologous muscle cells were able to restore the architecture of the urethra, but were eliminated from the first week on, before incorporation. Microcirculation of the neourethra, at the end of the third month, showed the same characteristics as a normal urethra in both groups of animals.

Conclusion: Natural heterologous matrices implanted in the urethra as onlay graft were not incorporated into its walls but were able to fully restore the cell architecture of the organ, regardless of being seeded or not with autologous muscle cells.
ARTICLE INFO

\section{Key words:}

Urethra; Surgical Procedures, Operative; Tissue Engineering; Microcirculation

Int Braz J Urol. 2013; 39: 414-23

Submitted for publication:

February 27, 2012

Accepted after revision: April 29, 2013

\section{INTRODUCTION}

Urethral reconstruction is frequently used in the treatment of both congenital and acquired anomalies (1-6). When the urethra needs to be repaired or reconstructed, either partially or totally, different surgical approaches can be used such as anastomosis of the urethral stumps, flaps or grafts. Although such techniques are still largely employed, in several occasions adverse effects such as fistulas, stenosis, infections, stone formation, graft contracture or diverticula formation may 
appear. In addition to morbidity at the donor site, there is tissue scarcity when such patients undergo a number of surgical interventions (1,2,4-12).

Tissue engineering techniques are an alternative for such difficulties. A decellularized matrix, either natural or synthetic, may serve as a pattern for implantation of individual cells previously obtained by harvesting a full fragment from the very organ. The different cell layers are separated by using different techniques, expanded "in vitro", and then seeded in the matrix before reimplantation (5). The different researchers that use cell-seeded matrices describe the process of matrix incorporation into the new urethra, however, not observing the manner in which this incorporation actually takes place in the early phases of tissue repair.

This paper aimed to study the evolution of decellularized heterologous matrices integration along time, whether or not seeded with autologous smooth muscle cells and implanted into the urethra.

\section{MATERIALS AND METHODS}

All experimental procedures were approved by the local Research Ethics Committee (CEP 0939/07) and conducted in strict conformity with local institutional guidelines and with international standards for manipulation and care of laboratory animals.

Eighteen New Zealand male rabbits, 6 to 8 months old, weighing approximately $3 \mathrm{~kg}$, from the Center for Development of Experimental Models for Medicine and Biology of the Federal University of São Paulo, were used. The animals were assigned to 2 groups of nine animals each. The animals in both groups underwent resection of a $3.5 \mathrm{~cm}$ long by 0.5 $\mathrm{cm}$ wide fragment from the ventral portion of the penile urethra. The animals in Group I underwent interposition of a patch of decellularized heterologous matrices, of same size as the urethral segment withdrawn, seeded with autologous muscle cells; the animals in Group II underwent interposition of decellularized heterologous matrix patches, of same size as the segment withdrawn, however with no cells seeded. The matrix was sutured to the urethra using 6-0 polypropylene in a continuous fashion.
The collagen matrices were taken from porcine bladders submucosa obtained from animals undergoing different surgical procedures. They were kept in sterile tubes containing $50 \mathrm{ml}$ PBS (Phosphate-Buffered Saline - Sigma Chemical Co., Saint Louis, USA), to which $10.000 \mathrm{Ul} / \mathrm{L}$ penicillin and $50 \mathrm{mg} / \mathrm{L}$ streptomycin were added. They were continuously agitated for fourteen days in Triton X-100 1\% detergent (Sigma Chemical CO, Saint Louis, USA) and $0.1 \%$ ammonia hydroxide, which solution was changed every two days. On day fourteen the bladders were kept for twenty-four hours in distilled water in continuous agitation. Then, they underwent ultraviolet radiation for one hour and, after that, they were cut into $3 \times 5 \mathrm{~cm}$ fragments under a laminar flow chamber. The fragments were then kept in tubes containing sterile PBS and stored at $-20^{\circ} \mathrm{C}$ Celsius until they were used. A fragment of the material obtained was put in a 10\% tamponade formaldehyde solution and forwarded for anatomopathological assessment.

For the surgical procedures the animals were anesthetized with intramuscular ketamine $(50 \mathrm{mg} /$ $\mathrm{kg}$ ) and xylazine $(10 \mathrm{mg} / \mathrm{kg})$. During the procedures a venous infusion of physiological solution was maintained. The animals in Group I underwent median laparotomy. The bladder was isolated and a $1 \mathrm{~cm} 2$ segment was withdrawn from the anterior wall; the bladder was then sutured with 4-0 polyglactin and the abdominal wall was sutured with 3-0 polyglactin. The bladder fragment withdrawn was taken to the laminar flow chamber and cut into $2 \mathrm{~mm} 2$ fragments after full removal of the mucosa. The fragments were placed on culture plates by using the "explant" technique, covered with Dulbecco's modified Eagle's medium (DMEM) and 10\% fetal bovine serum, and incubated at $37^{\circ} \mathrm{C}$ in a $5 \%$ carbon dioxide atmosphere. Around day fourteen, when the culture plates showed cell confluence of approximately 80\%, they were subjected to trypsin enzymatic action. The solution was centrifuged, the cells were counted in a Neubauer chamber and seeded in the collagen matrix, where they remained for another seven days in the same culture solution before being implanted.

The animals from both groups were sacrificed by anesthetic deepening; two animals on days seven, fourteen and twenty-eight and 3 animals in the third postoperative month. One animal in every sacrifice period had its bladder and urethra removed 
in block for a cystourethrography. The penises of all animals were removed in block and fixed in 10\% buffered formaldehyde for 24 hours. The pieces were placed in paraffin blocks, cut into 5 micrometer sections, stained with hematoxylin-eosin (H\&E), Masson trichrome (MT), Picrosirius red and assessed with polarized light and immunohistochemistry using anti-Von Willebrand factor antibody and analyzed in optical microscopy with 150x augmentation. We observed the epithelial integrity, the inflammatory process and the amount of collagen, and scores 0 to 3 were created for every item assessed (Table-1).

At the end of the third postoperative month one animal in every group underwent urethroscopy with an Olympus Winter \& Ibe GMBH, Hamburg, Germany, 17Fr sheath, 12 degree optics cystoscope and was assessed for the new urethra microcirculation through an SDF device, $1 \mathrm{~mm}^{2}$ images from three different sites were captured, a $2 \mathrm{~mm}^{\text {hh }}$ deep surface was assessed in 320x image augmentation; the images were saved in 10 second videos (13).

\section{RESULTS}

The urethroscopies performed showed the urethra with normal caliber - the 17Fr cystoscope was passed with no technical difficulty and an adequate urinary flow was obtained after bladder compression.

The microcirculation assessed by the SDF showed low flow through venules, scarce capillaries, absence of arterioles, and low vascular density; these results were similar to the ones observed in normal rabbits urethras (Figure-1).

The cystourethrografies performed showed urethras with normal caliber and adequate urinary flow (Figure-2).

Histological analyses performed on postoperative day seven showed a disrupted area with a deposit of fibrin-leukocitary material and stroma rich in leukocytes, with predominating polymorphonuclears and presence of eosinophils in the animals of both groups, suggestive of an acute exudative inflammatory process and of a recent intervention. The matrix was already being eliminated into the lumen of the organ, and an epithelial layer of cells was being formed right below (Figure-3). On day fourteen, in both groups, the matrix was found to be in the ure- thral lumen, the epithelium not fully formed yet, and the stroma with mixed inflammatory infiltrate with lymphocytes predominating, suggestive of an early chronification. The process was being resolved from bottom to top with good formation of the muscle layer (Figure-4). On day twenty-eight full reepithelization could already be observed in the animals in both groups with inflammatory process, with predominating lymphocytes, limited to the submucosa (Figure-5 a). A squamous metaplasia in the animals in the group without cells was observed (Figure-5 b). On day ninety the animals in both groups had urethral architecture similar to that of a normal urethra, however still with a less intense chronic inflammatory process, with predominating lymphocytes, showing the scarring not to be fully resolved on day ninety (Figure-6) The result of the assessment made by two pathologists in a blind study can be seen in Table-1.

Picrosirius red staining showed in all periods and in both groups, predominance of early type III collagen, even on day ninety (Figure-7).

Immunochemistry using anti-Von Willebrand antibody demonstrated intense neoangiogenisis in both groups, with no differences between them (Figure-8).

\section{DISCUSSION}

The need to partially or fully reconstruct the urethra is relatively usual given the high number of patients with congenital or acquired diseases, and trauma victims. Thus, a large number of techniques have been used in the attempt to restore the anatomy of the organ, aiming to achieve adequate micturition and, in the cases of male patients, to enable forward ejaculation with an adequate amount of spermatozoids (1-5,7). All techniques used to date have a high rate of complications and, when such patients undergo several procedures, which is quite usual, the use of flaps or grafts is almost always necessary $(5-7,14,15)$.

The surgical interventions employing grafts for urethral reconstruction have already led to the use of segments from the saphenous vein, from the appendix, from partial skin grafts and even from tissues containing urothelium, such as the ureter and bladder mucosa (14-23). Synthetic materials such as dacron ${ }^{\circledR}$, silicone and teflon ${ }^{\circledR}$, have also been used, but, more recently, the use of buccal muco- 
Figure 1 - A - Photomicrography of the urethra - group I (seeded matrix), SDF 320x. B - Photomicrography of the urethra group II (non-seeded matrix). SDF 320x.
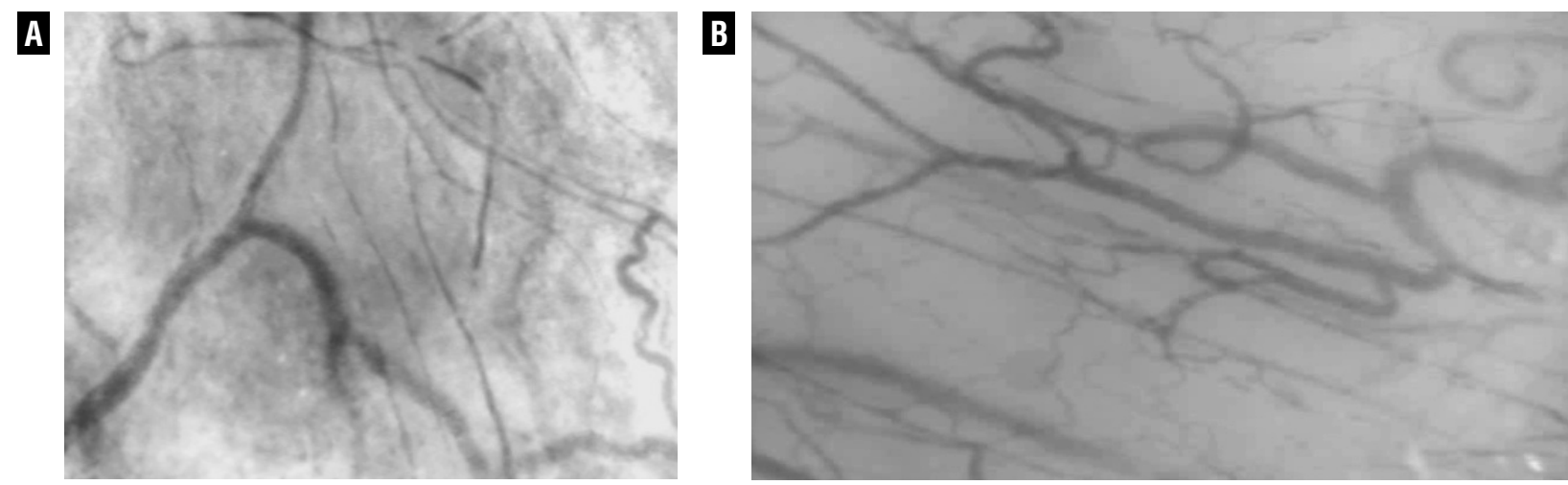

Figure 2 - A - Cystourethrography - Rabbit Group I (seeded heterologous matrix). Yellow line delimiting penile urethra subjected to matrix interposition. B - Cystourethrography Rabbit Group II (non-seeded heterologous matrix). Yellow line delimitating penile urethra subjected to matrix interposition.

\section{A}

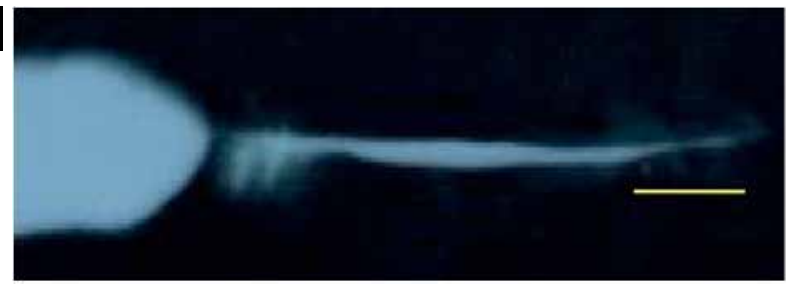

B

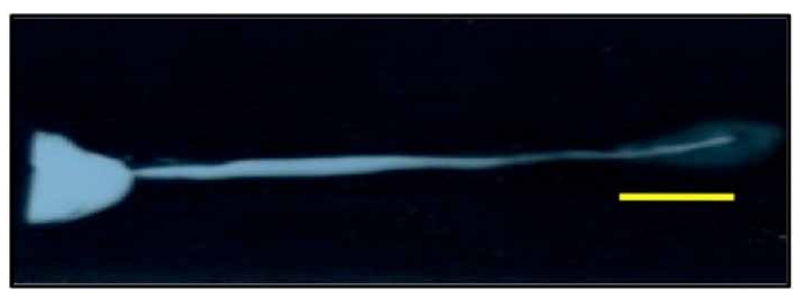

Figure 3 - A - Photomicrography of the urethra - Group I animal, postoperative day 7, Black arrow = Matrix. Green arrow = inflammatory process. Blue arrow = epithelium. H\&E 25x. B - Photomicrography of the urethra - Group II animal, postoperative day 7 , Black arrow $=$ Matrix. Green arrow $=$ inflammatory process. Blue arrow $=$ epithelium H\&E, 25x.

A

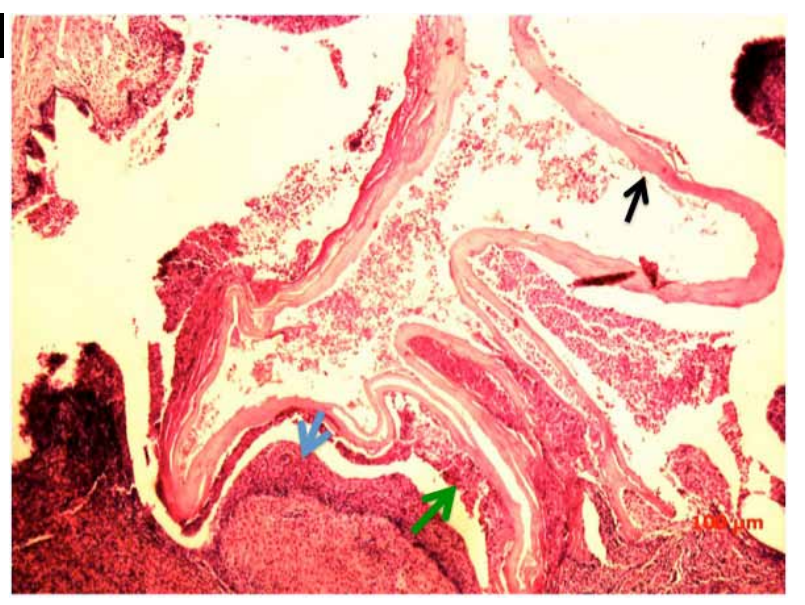

B

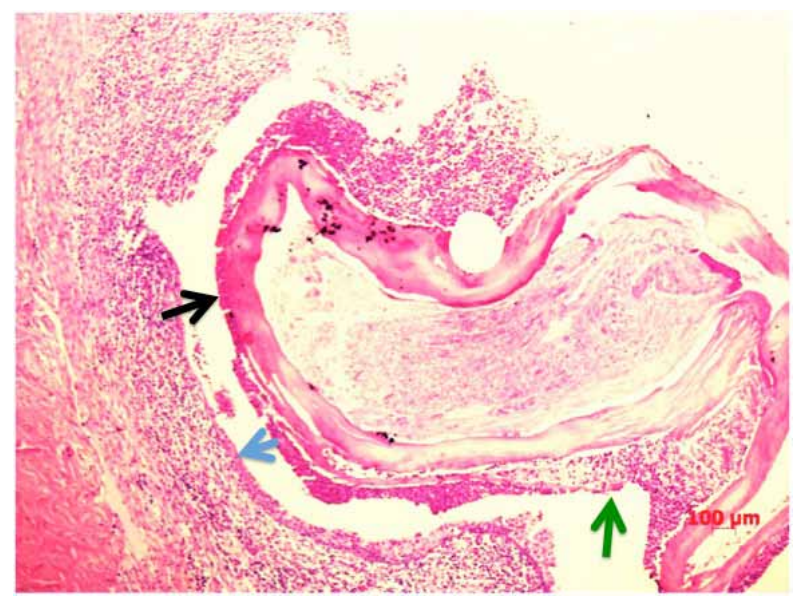


Table 1 - Anatomopathologic findings.

\begin{tabular}{|c|c|c|c|}
\hline Groups & Inflammation intensity & Predominant Cells & Layers \\
\hline \multirow[t]{2}{*}{$\begin{array}{l}7 \text { days } \\
\text { No cells }\end{array}$} & 3 & $\begin{array}{l}\text { Lymphocytes } \\
\text { Eosinophils } \\
\text { Neutrophils }\end{array}$ & $\begin{array}{l}\text { Submucosa } \\
\text { (ulceration) }\end{array}$ \\
\hline & 3 & $\begin{array}{l}\text { Lymphocytes } \\
\text { Eosinophils } \\
\text { Neutrophils }\end{array}$ & $\begin{array}{l}\text { Submucosa } \\
\text { Muscular }\end{array}$ \\
\hline \multirow[t]{2}{*}{$\begin{array}{l}7 \text { days } \\
\text { With cells }\end{array}$} & 3 & $\begin{array}{l}\text { Lymphocytes } \\
\text { Neutrophils }\end{array}$ & $\begin{array}{c}\text { Mucosa } \\
\text { Submucosa } \\
\text { Muscular }\end{array}$ \\
\hline & 3 & $\begin{array}{l}\text { Lymphocytes } \\
\text { Neutrophils }\end{array}$ & $\begin{array}{c}\text { Submucosa } \\
\text { Muscular }\end{array}$ \\
\hline \multirow[t]{2}{*}{$\begin{array}{l}14 \text { days } \\
\text { No cells }\end{array}$} & 3 & $\begin{array}{l}\text { Lymphocytes } \\
\text { Eosinophils } \\
\text { Neutrophils }\end{array}$ & Submucosa \\
\hline & 3 & $\begin{array}{l}\text { Lymphocytes } \\
\text { Neutrophils }\end{array}$ & $\begin{array}{c}\text { Submucosa } \\
\text { Muscular }\end{array}$ \\
\hline \multirow{2}{*}{$\begin{array}{l}14 \text { days } \\
\text { With cells }\end{array}$} & 2 & Lymphocytes & Submucosa \\
\hline & 2 & Lymphocytes & Submucosa \\
\hline \multirow[t]{2}{*}{$\begin{array}{l}28 \text { days } \\
\text { No cells }\end{array}$} & 2 & Lymphocytes & $\begin{array}{c}\text { Mucosa } \\
\text { Submucosa }\end{array}$ \\
\hline & 3 & Lymphocytes & $\begin{array}{c}\text { Mucosa } \\
\text { Submucosa }\end{array}$ \\
\hline \multirow{2}{*}{$\begin{array}{l}28 \text { days } \\
\text { With cells }\end{array}$} & 1 & Lymphocytes & Submucosa \\
\hline & 3 & $\begin{array}{l}\text { Neutrophils } \\
\text { Lymphocytes }\end{array}$ & $\begin{array}{c}\text { Mucosa } \\
\text { Submucosa }\end{array}$ \\
\hline
\end{tabular}


continuation

$\begin{array}{lccr}3 \text { months } & 1 & \text { Lymphocytes } & \text { Submucosa } \\ \text { No cells } & & \text { Eosinophils } & \text { Neutrophils } \\ & 2 & \text { Lymphocytes } & \text { Submucosa } \\ & 2 & \text { Lymphocytes } & \text { Submucosa } \\ 3 \text { months } & 2 & \text { Neuthrophils } & \text { Mucosa } \\ \text { With cells } & & \text { Lymphocytes } & \text { Submucosa } \\ & 2 & \text { Neuthrophils } & \text { Submucosa } \\ & & \text { Lymphocytes } & \text { Submucosa }\end{array}$

0 - No inflammatory process

1 - Mild amount of inflammatory cells

2 - Moderate amount of inflammatory cells (more than $25 \%$ of the sample)

3 - Extended or severe inflammatory process (more than $50 \%$ of the sample)

Neutrophils - Acute Inflammation

Lymphocytes - Chronic Inflammation

Eosinophils - Exsudation

Figure 4 - A - Photomicrography of the urethra - group I animal, postoperative day 14, Blue arrow = epithelium Masson's trichrome, 25x. B - Photomicrography of the urethra - Group II animal, postoperative day 14, Blue arrow = epithelium. Masson's trichrome, 25x.
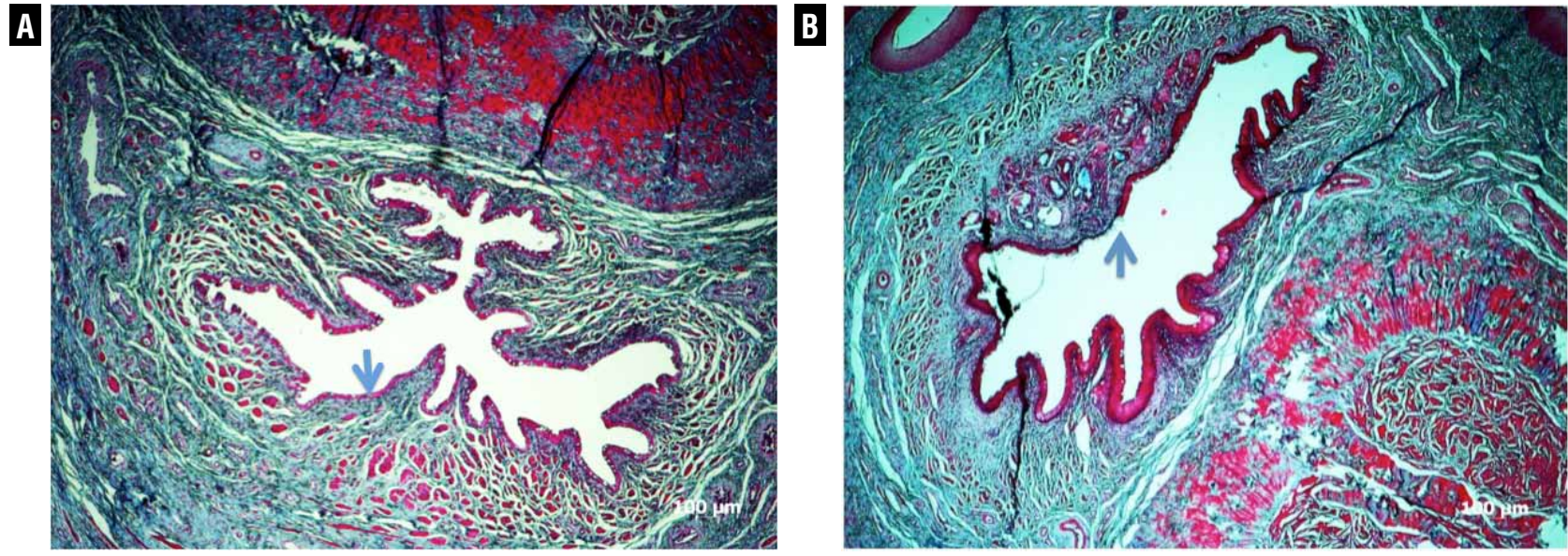
Figure 5 - A - Photomicrography of the urethra - Group I animal, postoperative day 28, H\&E, 25x. B - Photomicrography of the urethra - Group II animal, postoperative day 28. Blue arrow = squamous metaplasia. Masson's trichrome, 25x.

A

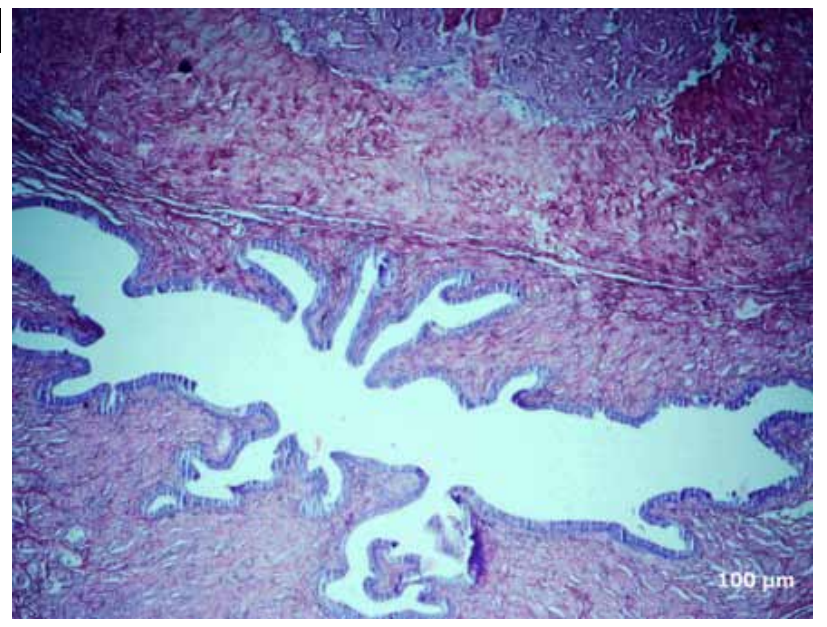

B

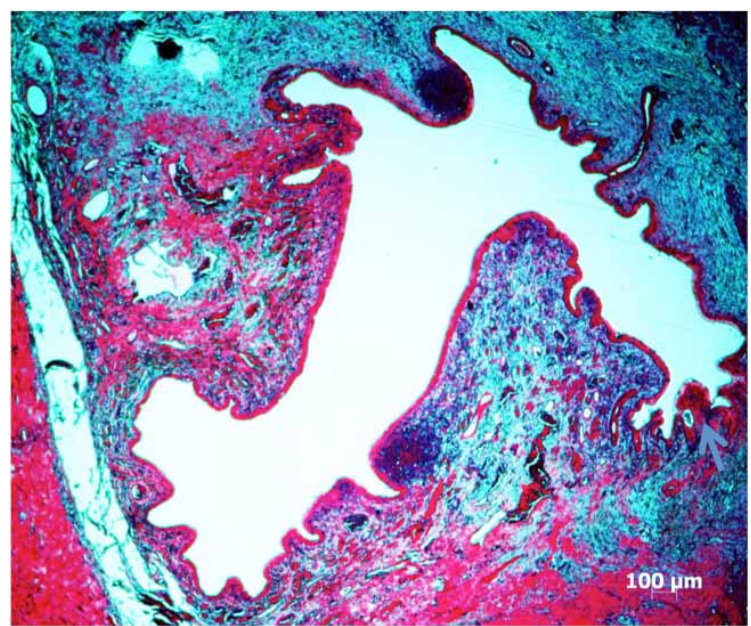

Figure 6 - A - Photomicrography of the urethra - Group I animal, postoperative day 90, Masson's trichrome, 25x. B - Photomicrography of the urethra - Group II animal, postoperative day 90, Masson's trichrome, 25x.

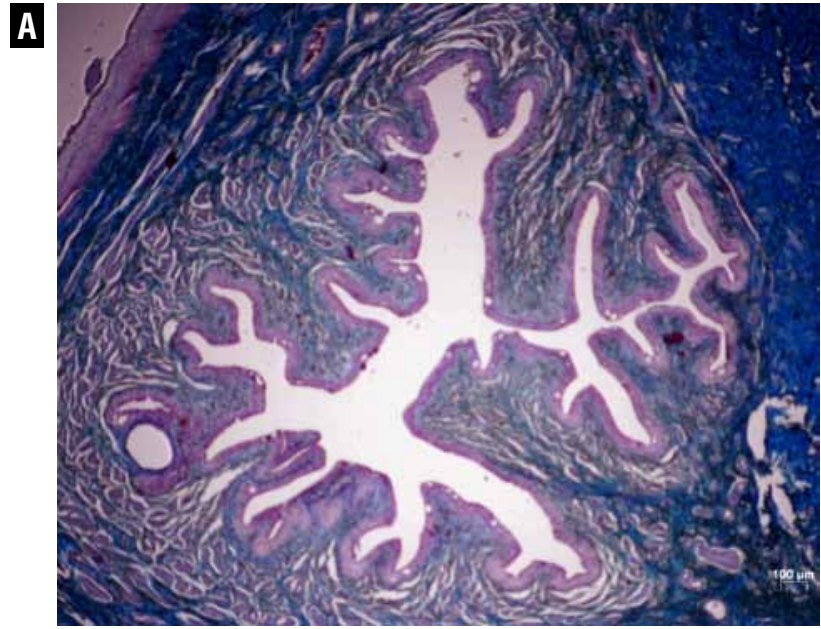

sa appears to have become the gold standard in the treatment of major reconstructions, presenting the smallest rate of stenosis and fistulas, in the medium and long term. The number of adverse events, however, does not allow one to say yet that this would be the ideal urethral substitute (12,23-26).

The recent advance of molecular biology, the large scale production of cell nutrients, and the possibility of cultivating cells "in vitro" and then implanting them in synthetic or natural ex-

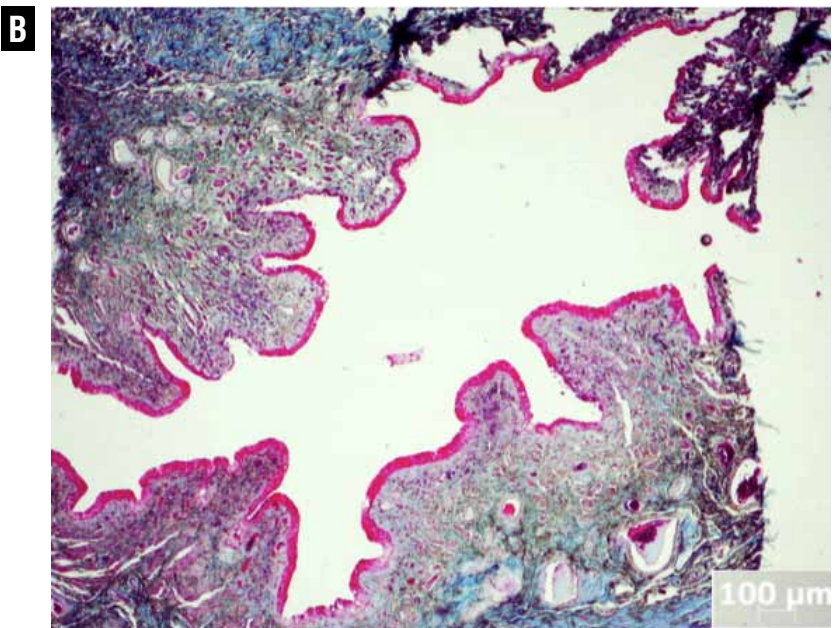

tracellular matrices, thus reconstructing an organ, have led to the introduction of Tissue Engineering techniques. Combined with the employment of new materials these techniques may become important in the reconstruction or replacement of lost or insufficient organs or tissues, and a viable option in cases of lack or partial absence of tissues (5,27-29).

Tissue Engineering uses either natural or synthetic matrices that should favor cell adhesion, proliferation, differentiation, and growth, and 
Figure 7 - A - Photomicrography of the urethra - Group I animal, postoperative day 90, Picrosirius Red staining, 25x. Green area collagen (type III). B - Photomicrography of the urethra - Group II animal, postoperative day 90, Picrosirius Red staining, 25x. Blue area collagen (type III)
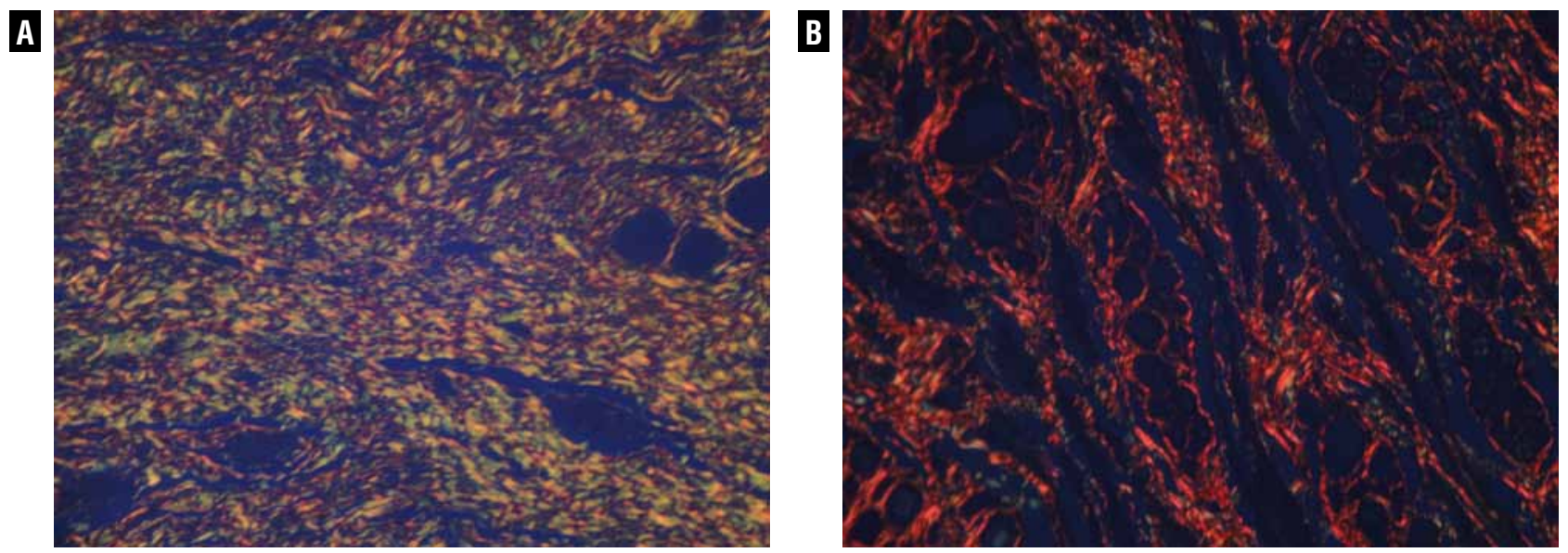

Figure 8 - A - Photomicrography of the urethra - Group I animal, postoperative day 90, immunohistochemistry with anti-Von Willebrand factor antibodies, 25x. B - Photomicrography of the urethra - Group II animal, postoperative day 90, immunohistochemistry with anti-Von Willebrand factor antibodies, 25x.

A

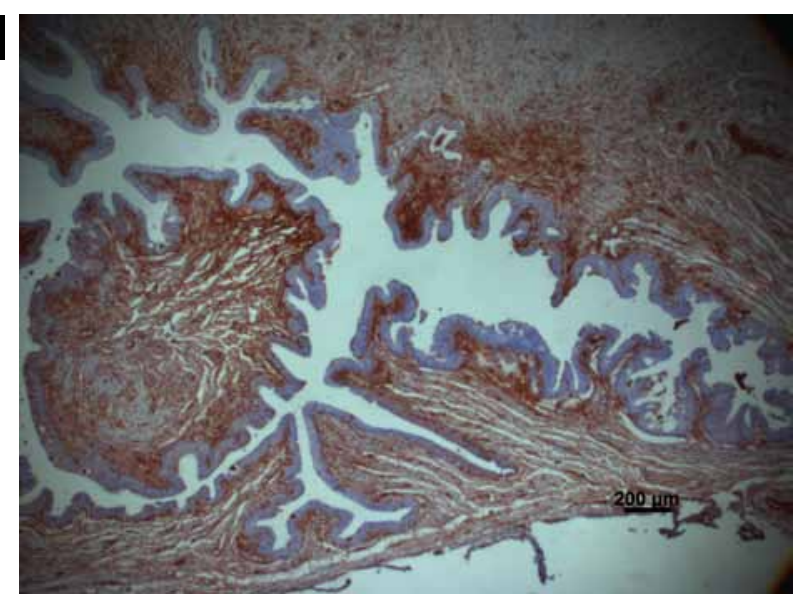

their slow degradation by lysosomal enzymes, in the case of synthetic matrices that gradually lead to their absorption, with minimal toxicity and inflammatory reaction $(3,5,7,9,30,31)$. Tissue engineering techniques may allow for the creation of a reservoir of biocompatible tissues that can be used in extensive urethral reconstructions when there is a lack of autologous tissues for flaps or grafts on account of various prior surgeries.

In this study we sought to assess integration of a collagen matrix into the urethral wall. The collagen matrix was obtained of a porcine
B

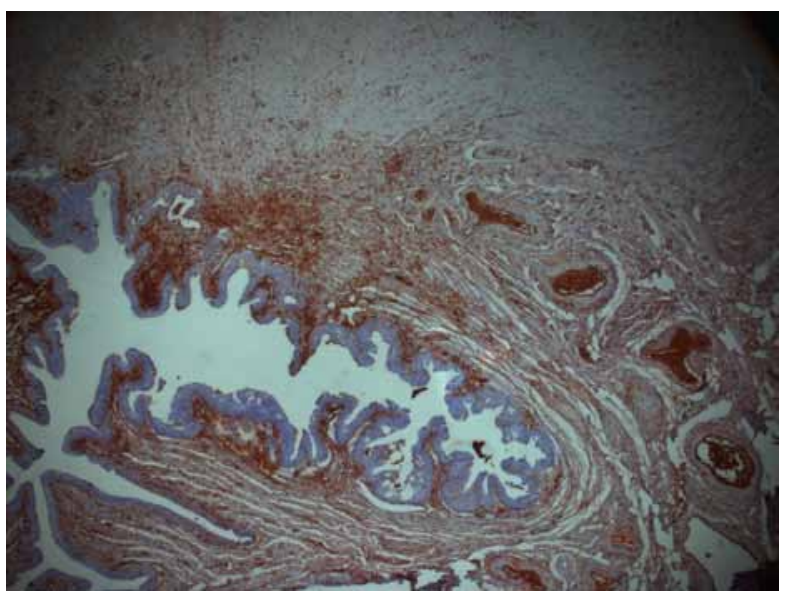

bladder by employing tissue engineering techniques. Considering that in the different reconstruction techniques, urothelial growth frequently takes place starting from the lateral borders in the transition between the patient's urethra and the graft, we decided to test the hypothesis that implantation of the autologous smooth muscle cells alone with no need to use the urothelial layer could reconstruct the entire architecture of the organ. It was found, through endoscopy and radiographic exams, that the macroscopic aspect of the urethral caliber of the animals in both groups 
studied resembled that of a non-operated urethra, fact that had previously been observed by Chen et al., Atala et al. and El-Kassaby et al. using similar techniques $(1,2,5,7,8)$.

By using the SDF it was possible to assess the microcirculation that was established on the new urethra around postoperative day ninety; it also showed the vascular network to resemble that of a normal urethra, regardless of the matrix having or not been seeded with muscle cells.

In order to verify the process of incorporation of the matrices into the urethral bed, histological assessment with hematoxylin-eosin, Masson's trichrome, Picrosirius red and Von Willebrand staining were used. On day seven after implantation the animals in both groups had the same behavior in regard to epithelial integrity, to the inflammatory process and to the amount and type of collagen. The implanted matrix, instead of being incorporated and forming a portion of the urethral wall, was being eliminated into the organ's lumen while, at the same time, the anatomy of the urethra was being restored. On postoperative days twenty-eight and ninety both groups showed epithelial integrity; the only difference found was that on day twenty-eight most of the animals in which the cells were not seeded had squamous metaplasia, which means the existence of an intense inflammatory process that turns the original epithelium into a barrier that is more resistant to aggressions.

Decellularized collagen matrices of different origins are being used in urethral reconstructions. Chen et al observed cell infiltration and neoangiogenesis after two weeks, with disorganized migration of muscle fibers after two months (2). De Filippo et al comparing decellularized matrices seeded or not with epithelial and muscle cells observed scarce vascular organization in the non-seeded matrices, contrasting with the good organization of the ones seeded (4). Our study was the first to make an early assessment of the heterologous matrices integration process. We demonstrated that the matrix was actually eliminated into the lumen instead of being reincorporated, and the reason for such may be a possible greater matrix permeability to the urine, which can be explained, perhaps, by an exaggerated inflammatory process.
Regardless of being incorporated, however, the entire layer was reconstructed, which may have occurred in other studies, considering that, apparently, what really matters seems to be the presence of the matrix at the beginning of scarring.

It can be said that the heterologous collagen matrix, although not having been integrated into the native tissue, was capable of stimulating urethral remodeling when the dorsal bed of the original urethra was maintained. In those cases muscle cells seeding was not necessary for the urethral remodeling to be completed, and autologous smooth muscle cells seeding, although having lessened the inflammatory process, was not found to be indispensable for regeneration of both the original muscle and the epithelial layer.

\section{CONCLUSIONS}

Natural heterologous matrices implanted in the urethra as onlay graft were not incorporated into the urethral walls but were capable of restoring its entire cell architecture whether or not seeded with autologous muscle cells.

\section{ACKNOWLEDGMENTS}

We would like to thank Drs. Daniel Eberli and James Yoo, from the Wake Forest Institute for Regenerative Medicine, NC, USA, for their technical support and Maria Cristina Carnevale for editorial assistance with this manuscript.

\section{CONFLICT OF INTEREST}

None declared.

\section{REFERENCES}

1. Chen F, Yoo JJ, Atala A: Acellular collagen matrix as a possible "off the shelf" biomaterial for urethral repair. Urology. 1999; 54: 407-10.

2. Chen F, Yoo JJ, Atala A: Experimental and clinical experience using tissue regeneration for urethral reconstruction. World J Urol. 2000; 18: 67-70.

3. Bisson I, Hilborn J, Wurm F, Meyrat B, Frey P: Human urothelial cells grown on collagen adsorbed to surface-modified polymers. Urology. 2002; 60: 176-80. 
4. De Filippo RE, Yoo JJ, Atala A: Urethral replacement using cell seeded tubularized collagen matrices. J Urol. 2002; 168: 1789-92; discussion 1792-3.

5. Atala A: Tissue engineering for the replacement of organ function in the genitourinary system. Am J Transplant. 2004; 4(Suppl 6): 58-73.

6. Kropp BP, Ludlow JK, Spicer D, Rippy MK, Badylak SF, Adams MC, et al.: Rabbit urethral regeneration using small intestinal submucosa onlay grafts. Urology. 1998; 52: 138-42.

7. Atala $A$, Guzman $L$, Retik $A B$ : A novel inert collagen matrix for hypospadias repair. J Urol. 1999; 162: 1148-51.

8. El-Kassaby AW, Retik AB, Yoo JJ, Atala A: Urethral stricture repair with an off-the-shelf collagen matrix. J Urol. 2003; 169: 170-3; discussion 173.

9. Fossum M, Svensson J, Kratz G, Nordenskjöld A: Autologous in vitro cultured urothelium in hypospadias repair. $J$ Pediatr Urol. 2007; 3: 10-8.

10. Dorin RP, Pohl HG, De Filippo RE, Yoo JJ, Atala A: Tubularized urethral replacement with unseeded matrices: what is the maximum distance for normal tissue regeneration? World J Urol. 2008; 26: 323-6.

11. Feng $C, X u$ YM, Fu Q, Zhu WD, Cui L, Chen J: Evaluation of the biocompatibility and mechanical properties of naturally derived and synthetic scaffolds for urethral reconstruction. J Biomed Mater Res A. 2010; 94: 317-25.

12. Dessanti A, Rigamonti W, Merulla V, Falchetti D, Caccia G: Autologous buccal mucosa graft for hypospadias repair: an initial report. J Urol. 1992; 147: 1081-3; discussion 1083-4.

13. De Backer D, Hollenberg S, Boerma C, Goedhart P, Büchele $G$, Ospina-Tascon G, et al.: How to evaluate the microcirculation: report of a round table conference. Crit Care. 2007; 11: R101.

14. Memmelaar $\mathrm{J}$ : Use of bladder mucosa in a one-stage repair of hypospadias. J Urol. 1947; 58: 68-73.

15. Caldamone AA, Edstrom LE, Koyle MA, Rabinowitz R, Hulbert WC: Buccal mucosal grafts for urethral reconstruction. Urology. 1998; 51: 15-9.

16. Schmieden V: New method of operation for male hypospadias: free transplant of ureter to form urethra. Arch Klin Chir 1909; 90: 748.
17. El-Sakka Al, Lue TF: Venous grafting for the correction of penile curvature in Peyronie's disease. Curr Opin Urol. 1998; 8: 541-6.

18. Lexer E: Free transplantation: Ann Surg. 1914; 60: 166-94.

19. Leveuf J, Godard H: La greffe temporaire de la verge sur le scrotum dans le traitement de l'hypospadias. J Chir 1936; 48: 328.

20. McIndoe A: Deformities of the male urethra. Br J Plast Surg. 1948; 1: 29-47.

21. Humby G: A one stage operation for hypospadias. Brit. J. Surg. 1941; 29: 84-92.

22. Devine CJ Jr, Horton CE: A one stage hypospadias repair. J Urol. 1961; 85: 166-72.

23. Coleman JW, McGovern JH, Marshall VF: The bladder mucosal graft technique for hypospadias repair. Urol Clin North Am. 1981; 8: 457-62.

24. Hakky SI: Urethral replacement by "dacron" mesh. Lancet. 1976; 2: 1192.

25. Hakky SI: The use of fine double siliconised dacron in urethral replacement. Br J Urol. 1977; 49: 167-71.

26. Anwar H, Dave B, Seebode JJ: Replacement of partially resected canine urethra by polytetrafluoroethylene. Urology. 1984; 24: 583-6.

27. Hodde J: Naturally occurring scaffolds for soft tissue repair and regeneration. Tissue Eng. 2002; 8: 295-308.

28. Eberli D, Freitas Filho L, Atala A, Yoo JJ: Composite scaffolds for the engineering of hollow organs and tissues. Methods. 2009; 47: 109-15.

29. Raya-Rivera A, Esquiliano DR, Yoo JJ, Lopez-Bayghen E, Soker S, Atala A: Tissue-engineered autologous urethras for patients who need reconstruction: an observational study. Lancet. 2011; 377: 1175-82.

30. Wünsch L, Ehlers EM, Russlies M: Matrix testing for urothelial tissue engineering. Eur J Pediatr Surg. 2005; 15: 164-9.

31. Kim BS, Atala A, Yoo JJ: A collagen matrix derived from bladder can be used to engineer smooth muscle tissue. World $\mathrm{J}$ Urol. 2008; 26: 307-14.

\footnotetext{
Correspondence address:

Dr. Luiz G. Freitas Filho

Rua Batista Cepelos 87 / 61

São Paulo, SP, 04109-120, Brazil

Fax: + 5511 5571-7965

E-mail: luizfreitasepm@gmail.com
} 